\title{
Methods for Conducting Trends Analysis: Roadmap for Comparing Outcomes from Three National HIV Population-Based Household Surveys in Kenya (2007, 2012, and 2018)
}

\author{
Thomas Achia ( $\nabla$ yrb2@cdc.gov) \\ Centers for Disease Control and Prevention \\ Ismael Flores Cervantes \\ Westat \\ Paul Stupp \\ Centers for Disease Control and Prevention \\ Paul Musingila \\ Centers for Disease Control and Prevention \\ Jacques Muthusi \\ Centers for Disease Control and Prevention \\ Anthony Waruru \\ Centers for Disease Control and Prevention \\ Mary Schmitz \\ Centers for Disease Control and Prevention \\ Megan Bronson \\ Centers for Disease Control and Prevention \\ Gregory Chang \\ Centers for Disease Control and Prevention \\ John Bore \\ Kenya National Bureau of Statistics \\ Leonard Kingwara \\ National AIDS and STI Control Program \\ Samuel Mwalili \\ Jomo Kenyatta University \\ James Muttunga \\ Kenya Medical Research Institute \\ Joshua Gitonga \\ National AIDS Control Council \\ Kevin M. de Cock \\ Centers for Disease Control and Prevention \\ Peter Young \\ Centers for Disease Control and Prevention
}

\section{Research Article}

Keywords: HIV, trends, survey design, stratification, survey weights, clustering, multistage sampling

Posted Date: October 13th, 2021

DOI: https://doi.org/10.21203/rs.3.rs-924182/v1

License: (c) (i) This work is licensed under a Creative Commons Attribution 4.0 International License. Read Full License 


\section{Abstract}

\section{Background}

For assessing the HIV epidemic in Kenya, a series of independent HIV indicator household-based surveys of similar design can be used to assess trends in key indicators relevant to HIV prevention and control and to describe geographic and sociodemographic disparities, assess the impact of interventions, and develop strategies. We developed methods and tools to facilitate a robust analysis of trends across three national householdbased surveys conducted in Kenya in 2007, 2012, and 2018.

\section{Methods}

We used data from the 2007 and 2012 Kenya AIDS Indicator surveys (KAIS 2007 and KAIS 2012) and the 2018 Kenya Population-based HIV Impact Assessment (KENPHIA 2018). To assess the design and other variables of interest from each study, variables were recoded to ensure that they had equivalent meanings across the three surveys. After assessing weighting procedures for comparability, we used the KAIS 2012 nonresponse weighting procedure to revise normalized KENPHIA weights. Analyses were restricted to geographic areas covered by all three surveys. The revised analysis files were then merged into a single file for pooled analysis. We assessed distributions of age, sex, household wealth, and urban/rural status to identify unexpected changes between surveys.

To demonstrate how a trend analysis can be carried out, we used continuous, binary, and time-to-event variables as examples. Specifically, temporal trends in age at first sex and having received an HIV test in the last 12 months were used to demonstrate the proposed analytical approach. These were assessed with respondent-specific variables (age, sex, level of education, and marital status) and household variables (place of residence and wealth index). All analyses were conducted in SAS 9.4, but analysis files were created in Stata and R format to support additional analyses.

\section{Results}

This study demonstrates trends in selected indicators to illustrate the approach that can be used in similar settings. The incidence of early sexual debut decreased from 7.99 (95\% Cl: 7.67-8.33) per 1,000 person-years at risk in 2007 to 6.68 (95\% Cl: 6.35-7.02) per 1,000 person-years at risk in

2012 and to 6.62 (95\% Cl: $6.4-6.85)$ per 1,000 person-years at risk in 2018 . HIV-testing rates increased from $12.6 \%(95 \% \mathrm{Cl}$ : $11.6 \%-13.6 \%)$ in 2007 to $56.1 \%(95 \% \mathrm{Cl}: 54.6 \%-57.6 \%)$ in 2012 but decreased slightly to $55.6 \%$ [95\% Cl: $54.6 \%-56.6 \%)$ in 2018.

\section{Conclusions}

Our approach can be used to support trend comparisons for variables in HIV surveys in low-income settings. Independent national household surveys can be assessed for comparability, adjusted as appropriate, and used to estimate trends in key indicators. Analyzing trends over time can not only provide insights into Kenya's progress toward HIV epidemic control but also identify gaps.

\section{Introduction}

Despite the rapid increase in antiretroviral therapy (ART) use over the past two decades and the corresponding decline in mortality, in 2017, one-third of people in East and Southern Africa and less than half of the people in West and Central Africa who are living with HIV are not currently receiving any treatment [1, 2]. In 2017, HIV/AIDS was a major cause of death in sub-Saharan Africa (SSA), where $71 \%$ of all people living with HIV resided. Globally, $75 \%$ of HIV-related deaths and $65 \%$ of all new HIV infections occurred in SSA [3-5].

Against this background, it is important to assess whether interventions over the last two to three decades have decreased HIV incidence and to identify geographic regions and sociodemographic groups with high HIV prevalence [3, 6]. HIV data obtained from national population-based surveys play an important role in monitoring the HIV epidemic and response in the general population. These surveys estimate incidence, prevalence, and various parameters related to the HIV pandemic in high-HIV-prevalence countries. These surveys were designed to monitor progress toward ending the AIDS epidemic [6-8]. Additionally, they were designed to monitor the UNAIDS $90-90-90$ targets by the year 2020 : $90 \%$ of all HIVpositive people know their HIV status; of these, $90 \%$ are receiving sustained ART; and of these, $90 \%$ have viral load suppression [9-11]. These surveys have also been used to describe associations between high-risk behavior and HIV status and to assess HIV prevention, care, and treatment services.

Unlike in high-income countries where longitudinal studies provide nationally representative trend estimates for health outcomes, for example, the National Health and Nutrition Examination Survey [12,13], HIV surveys in low-income countries and high-prevalence settings are generally crosssectional and are independently implemented approximately every 5 years. Therefore, it is important to develop methods that can be used to assess trends across independent surveys for countries interested in employing similar techniques. We used Kenya to showcase this approach as there had been several HIV population-based surveys conducted, with varying sampling and survey weighting considerations, in the past two decades. Such methods must account for differences in survey design, weighting, coverage, and indicator definitions. Over the past two decades, five national population-based surveys [14-18] have included HIV testing and HIV modules in their algorithms in Kenya. 
We present methods that can be used to assess temporal trends in outcome variables of interest as a means to answer such questions as: "Has HIV risk behavior significantly declined over time in Kenya, and if so, in which demographic groups or regions?" and "Has access to HIV testing services increased over time in Kenya?" Our tools also can help HIV programs appropriately analyze trends in recent population-based HIV surveys in Kenya and provide guidance regarding appropriate statistical comparisons between surveys, including tests for trends. These suggestions may also serve as a roadmap for other cross-survey comparison analyses applicable to other countries or indicators. The methods presented here are being utilized to examine trends in specific indicators of interest in other KENPHIA-focused studies. Therefore, the programmatic implications of selected trends comparison presented in this study are not discussed.

\section{Methods}

\section{Harmonization of survey datasets}

\section{Analysis approach}

First, we reviewed survey design documents to describe the survey design and weighting procedures used for all three surveys. We compared sampling design and survey weighting procedures across surveys to identify differences that could potentially influence comparisons. We developed an analysis strategy to both facilitate comparisons and minimize the influence of differences in survey design or weighting procedures on comparisons between survey estimates. Once we chose a weighting approach, we developed a list of variables to extract and harmonize across surveys based on perceived importance, availability, and consistency of definitions across surveys. Once extracted, the weighted estimates of these variables were assessed for consistency across surveys. Finally, we used selected variables to identify and describe appropriate statistical methods for comparisons and trend analysis.

\section{Data extraction and manipulation}

We reviewed data dictionaries and other survey documentation to identify relevant survey design and analysis variables pertaining to HIV biomarkers and behavioral and demographic variables across the three surveys for inclusion in the analysis.

\section{Survey design}

These surveys were originally designed to provide data used by various stakeholders to monitor Kenya's population and HIV-related health outcomes. This section briefly summarized the survey design and weighing approaches used in the surveys. All three surveys utilized two-stage stratified, cluster sampling designs based on the National Sample Survey and Evaluation Programme (NASSEP) household-based sample frames created by the Kenya National Bureau of Statistics and revised after each decennial population census.

KAIS 2007 was the first AIDS Indicator Survey conducted in Kenya to monitor progress on key indicators in the national HIV prevention, care, and treatment programs [16]. The survey was designed to obtain a nationally representative sample of persons aged 15-64 years and to provide estimates of HIV-related outcomes stratified by urban/rural residence and the 8 provinces. The first stage included a selection of 415 clusters (70\% rural and 30\% urban) from the NASSEP IV (based on the 1999 census); the second stage included selecting a sample of 25 households within each cluster.

KAIS 2012 selected 372 clusters from NASSEP V (based on the 2009 census) using a systematic random sampling method. KAIS 2012 sampled 9,300 households within 9 of the 10 National AIDS and STI Control Programme (NASCOP) programmatic regions: Nairobi, Central, Coast, Eastern North, Eastern South, Nyanza, Upper Rift, Lower Rift, and Western regions, designated as either urban or rural. The sampling frame was not available for the North-Eastern region at the time of the survey, and this region (and hence seven NASCOP regions) was excluded from the survey. The target population was persons aged 18 months -64 years. Half of the households were targeted for children aged 18 months-14 years. The survey was designed to provide estimates of HIV-related outcomes for adults aged 15-64 years stratified by urban/rural area and the nine included NASCOP regions.

Like KAIS 2012, KENPHIA 2018 also was based on NASSEP V. KENPHIA was a cross-sectional, household-based survey conducted among persons aged 0-64 years in 800 clusters from 96 urban/rural county strata covering the entire household population of Kenya. In 2012, following the promulgation of the 2010 Constitution of Kenya, these counties became the geographical units of devolved government in place of districts. Survey data collection was conducted from June 2018 to February 2019. Of the 34,610 persons targeted by the survey, 27,897 were adults aged 15-64 years, and 6,713 were children aged 0-14 years. One in three households were targeted for the inclusion of children. The survey was designed to provide estimates for adults aged 15-64 years for all 47 counties in Kenya.

Each of these studies were carried out in accordance with the Helsinki Declaration.

Table 1 presents detailed summaries of the three surveys.

\section{Weighting process}




\section{Stratification}

The KAIS 2007 design was stratified by district and residency (urban/rural). Urban areas were further stratified by socioeconomic status. Both KAIS 2012 and KENPHIA designs were stratified by county and residency. Household nonresponse adjustments in KAIS 2007 were computed by province and residency, whereas in KAIS 2012, they were computed by NASCOP region and residency, resulting in the following nineteen design strata: Nairobi (Urban), Central (Urban/Rural), Nyanza (Urban/Rural), North Rift (Urban/Rural), South Rift (Urban/Rural), Eastern North (Urban/Rural), Eastern South (Urban/Rural), Western (Urban/Rural), and Coast (Urban/Rural). In KENPHIA, household nonresponse adjustments were computed by county.

\section{Coverage}

The KAIS 2007 and KENPHIA surveys covered the entire national territory, but KAIS 2012 excluded one geographic region, North Eastern. Therefore, to ensure that differences in coverage did not bias trend analyses, this region was omitted from the analysis, thereby stratifying by 17 remaining NASCOP region/residency strata across all three surveys.

\section{Survey weighting}

To compensate for over- or under- sampling of cases or for disproportionate stratification along with the non-response, studies often include several types of survey weights in the datasets that are made available after the survey. Individual, child, and HIV-testing (blood) weights ensure that adults

aged 15-64 years, children aged 0-14 years, and individuals selected for HIV testing, respectively, are representative of the population sampled. The survey design and nonresponse weighting approach for KAIS 2007 and KAIS 2012 were similar, and so no adjustments were made to the weights used in these studies. The KENPHIA 2018 survey design weights differed from the KAIS design weights in that no household-level post-stratification adjustments were done, and nonresponse weights were developed using a least absolute shrinkage and selection operator regression and chisquare automatic interaction detection methodology rather than the simpler inverse proportional weighting done by sex and geographic area variables. Furthermore, post-stratification weights were developed to age and sex control totals from the national population projections for 2019 for KENPHIA. Therefore, to remove potential biases in comparisons resulting from the differing nonresponse and post-stratification weighting approaches, KENPHIA was reweighted to increase comparability between weighted estimates across the surveys.

\section{Revised KENPHIA weights}

A primary sampling unit (PSU) or enumeration area (EA) base weight was computed as the inverse of the probability of selection of the EA. No PSU nonresponse adjustment was made, apart from two ineligible EAs whose weights were set to 0 . A household's initial weight was then computed as a product of the PSU base weight and the inverse of the probability of selection of the household within the EA. An unknown eligibility household nonresponse adjustment was computed as a product of the household initial weight and the inverse of the probability of the household having unknown eligibility. The household weight was further adjusted for the eligible household member nonresponse rate.

Adult person-level weights were assumed equal to the household weight since all adults (aged $\geq 15$ years) were eligible in a household. In the case of children (aged 0-14 years), only children in every third household were included in KENPHIA 2018. The child weight was then computed as three times the household weight. For adults, nonresponse adjustments cells were created by NASCOP region, urban-rural residence, and sex, whereas nonresponse-weighting classes for children were not stratified by sex. The post-stratification cells are produced by NASCOP region and sex. The child weights were not post stratified.

A similar approach was used to compute the HIV-testing (blood) weights included in the study.

\section{Data manipulation and merging}

Using the three individual survey datasets, we created a dataset that included survey year, the design variables (weights, strata, and cluster), demographic characteristics, and HIV-specific indicators. The stratification variable in the combined dataset consisted of the 17 NASCOP regions. The cluster was uniquely characterized by the survey year and the cluster identifier in each survey. The weights in the combined dataset were normalized such that the normalized weights summed to the total number of respondents in each survey. The SAS program that combines the three datasets and renames and recodes variables to facilitate comparative analyses is available in Supplementary File 1.

To create the combined data file, we combined 2007, 2012, and 2018 files so that the number of respondents in the combined data file was the sum of the respondents from the three individual files. We then ensured that the analysis variables had the same names and values or categories in all three data files. Table 2 illustrates how the variables used in this analysis were redefined. Secondly, the approach to creating the new set of statistical weights is provided in Supplementary File 2.

The study investigators did not interact with human subjects or have access to identifiable data or specimens. This was a secondary data analysis using anonymized data from each of the surveys that were included.

Figure 1 describes our suggested approach for harmonization of variables and datasets to perform trend analysis. 
Ideally, a set of unchanging population characteristics could be used to assess the comparability of the original and re-weighted datasets before proceeding with trend analyses. In the absence of such ideal variables, several demographic characteristics such as age, sex, marital status, residency, wealth index, and education, which have predictable trends and have been measured in other surveys over time, can be assessed for trends. In this analysis, we assessed the weighted distribution of each of these variables and used survey-weighted logistic regression to assess changes in the selected characteristics over time (Table 3). We found that there was no significant difference (trend) in key demographic variables selected for comparative assessment of original and re-weighted KENPHIA 2018 datasets.

\section{Results}

\section{Illustrative statistical analysis}

Once the comparability of the revised and harmonized datasets is established, it is possible to carry out trend analysis on selected indicators. In our analysis, we selected trends in two behavioral indicators relevant to HIV programs: "Age of sexual debut among respondents aged 15-64 years" and "Tested for HIV in the past 12 months among respondents aged 15-64 years." We selected these example indicators to illustrate trend analysis for continuous, binary, and time-to-event variables (Figure 2). Trends were assessed visually and through regression methods, including adjustment for demographic variables to control for other changes in the population over time.

\section{Characteristics of the study population}

Table 4 summarizes the sociodemographic characteristics of study participants. Women were overrepresented in all three surveys with male to female ratios of 1.00:1.33 in KAIS 2007, 1.00:1.38 in KAIS 2012, and 1.00:1.24 in KENPHIA 2018. There was a significant linear decline in the proportion of respondents sampled from within rural settings over time (KAIS 2007, 77.7\% [95\% confidence interval (CI): $75.1 \%-80.3 \%$; KAIS 2012, $62.9 \%$ [95\% Cl: $60.5 \%-65.3 \%]$; and KENPHIA 2018, 60.7\% [95\% Cl: 58.6\%-62.8\%]). There were significant variations in the distribution of the respondents by education. Across the three surveys, most respondents had primary education. Marital status varied between surveys. The age structure was generally consistent over time, except for a spike in the 20-24 year age group in 2007, followed by a similar spike in the 25-29 year age group in 2012 and in the 30-34 year age group in 2018. This pattern was consistent with an age cohort moving through the survey populations due to changing fertility or child mortality patterns in the mid-1980s.

\section{Sexual debut}

Trends in sexual debut were initially assessed visually and through regression methods, including adjusted analyses including demographic variables to control for other changes in the population over time using SAS PROC SURVEYREG. In this case, we assumed that the outcome was continuous and emanated from a Gaussian distribution.

Table 5 provides an example of how one can present summaries, trends, and regression results for the analysis of a continuous covariate such as age at sexual debut by selected covariates. In general, the median age at sexual debut of the study participants has increased significantly over time. There was a monotonic increase in the median age at sexual debut by place of residence and wealth index. Age at sexual debut was consistently higher in urban areas and among individuals from the richest households. Age at sexual debut increased monotonically over time among the women, peaking in 2012 and decreasing substantially in 2018 . A similar pattern was observed for marital status, in which age at sexual debut increased substantially over time among the married respondents but peaked in 2012, decreasing substantially in 2018 among those who never married.

In addition to assessing sexual debut as a continuous outcome variable, we also assessed trends in early sexual debut. Early sexual debut was defined as first vaginal intercourse before 15 years of age [19-22]. The time taken until first sexual intercourse for anyone who had not had sex by the age of 15 years was considered to be censored. We used the Kaplan-Meier method to compute the survival probability (not having become sexually active by age 15 years) by each age. We used SAS, version 9.4, to produce separate Kaplan-Meier estimates for each level of the covariates of interest. A log-rank test is not available for complex survey data to assess equality of survival curves, but Cox models are available for complex survey data. For our analyses, we used SAS PROC LIFETEST and SAS PROC SURVEYPHREG. The incidence of early sexual debut decreased from 7.99 (95\% Cl: 7.67-8.33) per 1,000 person-years at risk in 2007 to 6.68 (95\% Cl: 6.35-7.02) per 1,000 person-years at risk in 2012 and to 6.62 (95\% Cl: 6.4-6.85) per 1,000 person-years at risk in 2018 (Table 6).

\section{Tested in the last 12 months}

We used SAS PROC SURVEYLOGISTIC to fit a survey-weighted logistic regression model to the binary outcome "Tested for HIV in the last 12 months." Table 7 presents trends in the rates of HIV testing in the past 12 months among individuals aged 15-64 years. The results suggest a significant increase in the HIV-testing rates over time when adjusting for all the covariates considered. HIV-testing rates increased from $12.6 \%$ (95\% Cl: $11.6 \%-13.6 \%$ ) in 2007 to $56.1 \%$ (95\% Cl: $54.6 \%-57.6 \%$ ) in 2012 but decreased slightly to $55.6 \%$ [95\% Cl: $54.6 \%-56.6 \%$ ) in 2018 . Further, based on the survey-weighted logistic regression, after adjustment for all covariates considered, HIV testing rates increased substantially over time. 
In Figure 2, we provide a rubric that can be used to make decisions about the statistical analysis to employ for a given analysis question based on various design considerations. The SAS program used to carry out the crosstabulation, the survey-weighted regression analysis, the survey-weighted logistic regression analysis, the survey-weighted regression, and the person-time analysis is available in Supplementary File 3.

\section{Discussion}

We developed an approach for assessing and harmonizing independent population-based surveys to assess trends in HIV-related indicators. After describing the methods used to design and weight each survey, we harmonized stratification, demographic variables, and survey weights to ensure comparability before proceeding with a trend analysis. In this analysis, the survey weights for the latest survey (KENPHIA 2018) were revised to ensure comparability with the previous two surveys. It is important to note that we developed these methods strictly to allow for comparisons between surveys. The methods are not meant to provide revised or improved estimates for the most recent survey analyzed (KENPHIA). The original weights for KENPHIA are optimal and should be used to analyze and present the results of the KENPHIA survey. Similar approaches to making comparisons between surveys are documented elsewhere in the literature [23-30]. For reproducibility, we also provide the analysis codes that demonstrate how the analysis was carried out and how the comparison was done.

The weighted distributions of demographic variables were consistent across surveys with some exceptions. There was an increasing proportion of the sample that resided in urban areas, as expected given broad development trends in Kenya. The age structure showed spikes in subsequent age groups across surveys, consistent with a cohort effect from reductions in fertility 15-20 years before the KAIS 2007 survey, given that the surveys were spaced at approximately 5-year intervals, consistent with the historical fertility reductions observed in the recent Demographic and Health survey [31] and census [13] in Kenya. Other differences are difficult to explain. For example, the sex distribution seemed skewed in 2007 , with $42 \%$ of the survey population being men, compared to higher proportions of in the other two surveys (48-49\%), perhaps indicating coverage issues among men in that survey.

We used two outcome variables expected to change over time (HIV testing and age at sexual debut) to demonstrate a methodology to carry out trend comparisons. For HIV testing in the last 12 months, we highlighted two approaches that can be used to assess trends in dichotomous outcomes. We first computed survey-weighted proportions and plotted the resulting trends over time by selected covariates. We then fitted logistic regression models with the year as a covariate, adjusting for age, sex, residence, marital status, and wealth index. This approach has been employed in several other previous studies. Trends in HIV-testing rates have also been discussed extensively in the literature [23-25]. The use of chi-square tests of trends and logistic regression were extensively used in the literature.

For age at sexual debut, we show two approaches for assessing trends for a continuous variable. Several studies have also used survey data from low-income countries to assess trends in the HIV-related outcomes considered in our analysis. Several studies have treated age at sexual debut as a time-to-event outcome, assessing this outcome variable's trends among different cohorts observed [32, 33]. These studies have used survival analysis-based approaches to assess trends in the outcome variables of interest. In our analysis, we used two approaches where the first ignored censoring in the age at sexual debut and presented a summary and regression-based results as an example of how trends in continuous outcome variables could be assessed [34]. We then used the survival approach and found a decrease in the risk of early sexual debut over time.

Our analysis is subject to several limitations. The trend comparison was based on using three time points (2007, 2012, and 2018), so we were only able to make relatively short-term assessments of the trajectory of the indicators considered. Previous studies used Cochran Armitage chi-square tests or z-tests to assess the significance of trends [35-38]. Survey weighted versions of this statistic were not implemented in our analysis due to limitations in the software we used. Another challenge encountered was the change in the definition of certain variables and indicators over time, adding uncertainty in interpreting the meaning of observed trends. Furthermore, not all the same questions were asked across the three surveys, making it difficult to analyze some of the outcomes across the three surveys. Our study did not address all relevant issues for every conceivable trend analysis that could be conducted with these surveys. For example, changes in HIV-testing algorithms may affect estimates. Great care is needed in interpreting results with potential underlying methodological differences. Finally, there are alternatives to population-based surveys for measuring trends in health conditions. For example, in 2018, Kenya established an HIV Case-Based Surveillance system to measure progress along the HIV care cascade to provide high-quality, timely, and reliable HIV data by population characteristics. Despite current limitations and challenges, this system will provide an opportunity for future assessment of trends based on a census of events rather than population-based sampling, as presented here.

\section{Conclusion}

We have provided approaches and considerations that can be used to support trend comparisons for various outcome variables in HIV surveys in low-income settings. Our approach has demonstrated that independent national household surveys conducted over time can be assessed for comparability, adjusted as appropriate, and used to estimate trends in key indicators. Analyzing trends over time can not only provide insights into Kenya's progress toward HIV epidemic control but also identify gaps in key HIV indicators.

\section{Abbreviations}

Page 6/22 
KAIS: Kenya AIDS Indicator surveys

KENPHIA: Kenya Population-based HIV Impact Assessment

ART: Antiretroviral therapy

SSA: Sub-Saharan Africa

NHANES: National Health and Nutrition Examination Survey

NASSEP: National Sample Survey and Evaluation Programme

KNBS: Kenya National Bureau of Statistics

NASCOP: National AIDS and STI Control Programme

PSU: primary sampling unit

EA: enumeration area

KEMRI: Kenya Medical Research Institute

IRB: Institutional Review Board

CDC: Centers for Disease Control and Prevention

UCSF: University of California, San Francisco

Cl: Confidence Interval

OR: Odds ratio

AOR: Odds ratio

DHS: Demographic and Health survey

\section{Declarations}

\section{Ethics approval and consent to participate}

The KAIS 2007 and KAIS 2012 protocols were approved by the Scientific Steering Committee and the Ethical Review Committee at the Kenya Medical Research Institute (KEMRI) and by the Institutional Review Board (IRB) at the U.S. Centers for Disease Control and Prevention (US CDC) and the Committee on Human Research of the University of California, San Francisco (UCSF).

The KENPHIA 2018 survey protocol was approved by the US CDC IRB, the Columbia University Medical Center IRB, and the Ethical Review Committee at the KEMRI. It was reviewed in accordance with the Helsinki Declaration with Centers for Disease Control (CDC) human research protection procedures and was determined to be research, but CDC investigators did not interact with human subjects or had access to identifiable data or specimens. All adults, 18 years or older provided written informed consent, while for children younger than 18 years old, parental/guardian informed written consent and the minor's assent were obtained before participants took part in the study. The study was carried out in accordance with the Helsinki Declaration.

\section{Conflict of interest}

The authors have no conflicts of interest to declare.

\section{Disclaimer}

The findings and conclusions in this report are those of the authors and do not necessarily represent the official position of the funding agencies.

\section{Attribution of support}

This analysis is based on data from the national data warehouse, which is supported by the President's Emergency Plan for AIDS Relief (PEPFAR) through the Centers for Disease Control and Prevention (CDC) under the terms of Grant Number U2GGH001226.

\section{Acknowledgments}

Page $7 / 22$ 
The authors thank the KENPHIA and KAIS field teams for their contribution during KENPHIA and KAIS data collection and all the children and families who participated in these national surveys.

\section{Authors' Contributions}

T.A., P.Y., and S.M. designed the study protocol and performed statistical analysis and interpretation. T.A. drafted the manuscript. T.A. and P.Y. participated in the data cleaning and statistical analysis. All authors read and approved the final manuscript.

\section{Availability of data and materials}

The datasets used and/or analyzed during the current study are available from the corresponding author upon reasonable request.

\section{Competing interest}

The author(s) declare(s) that they have no competing interests

\section{Funding}

All the work described in the paper was funded by Centers for Disease Control and Prevention (CDC). The authors are wholly responsible for the design of the study, conduct of the analyses, interpretation of the results, and writing the manuscript.

\section{Consent for publication}

Not applicable.

\section{Authors' information}

Not applicable.

\section{References}

1. Joint United Nations Programme on HIV/AIDS (UNAIDS): 2020 global AIDS update-seizing the moment-Tackling entrenched inequalities to end epidemics. In.; 2020.

2. Joint United Nations Programme on HIV/AIDS (UNAIDS): UNAIDS DATA 2020. In.; 2020.

3. Dwyer-Lindgren L, Cork MA, Sligar A, Steuben KM, Wilson KF, Provost NR, Mayala BK, VanderHeide JD, Collison ML, Hall JB: Mapping HIV prevalence in sub-Saharan Africa between 2000 and 2017. Nature 2019, 570(7760):189-193.

4. James SL, Abate D, Abate KH, Abay SM, Abbafati C, Abbasi N, Abbastabar H, Abd-Allah F, Abdela J, Abdelalim A: Global, regional, and national incidence, prevalence, and years lived with disability for 354 diseases and injuries for 195 countries and territories, 1990-2017: a systematic analysis for the Global Burden of Disease Study 2017. The Lancet 2018, 392(10159):1789-1858.

5. Roth GA, Abate D, Abate KH, Abay SM, Abbafati C, Abbasi N, Abbastabar H, Abd-Allah F, Abdela J, Abdelalim A: Global, regional, and national age-sex-specific mortality for 282 causes of death in 195 countries and territories, 1980-2017: a systematic analysis for the Global Burden of Disease Study 2017. The Lancet 2018, 392(10159):1736-1788.

6. Joint United Nations Programme on HIV/AIDS (UNAIDS): Monitoring the declaration of commitment on HIV/AIDS: guidelines on construction of core indicators: World Health Organization; 2005.

7. Ghys PD, Williams BG, Over M, Hallett TB, Godfrey-Faussett P: Epidemiological metrics and benchmarks for a transition in the HIV epidemic. PLoS medicine 2018, 15(10).

8. Justman JE, Mugurungi O, El-Sadr WM: HIV population surveys-bringing precision to the global response. New England Journal of Medicine 2018, 378(20):1859-1861.

9. Simbayi L, Zuma K, Zungu N, Moyo S, Marinda E, Jooste S, Mabaso M, Ramlagan S, North A, Van Zyl J: South African National HIV Prevalence, Incidence, Behaviour and Communication Survey, 2017: towards achieving the UNAIDS 90-90-90 targets. In. Human Sciences Research Council (HSRC); 2019.

10. Akullian A, Morrison M, Garnett GP, Mnisi Z, Lukhele N, Bridenbecker D, Bershteyn A: The effect of 90-90-90 on HIV-1 incidence and mortality in eSwatini: a mathematical modelling study. The Lancet HIV 2020, 7(5):e348-e358.

11. Green D, Tordoff DM, Kharono B, Akullian A, Bershteyn A, Morrison M, Garnett G, Duerr A, Drain PK: Evidence of sociodemographic heterogeneity across the HIV treatment cascade and progress towards 90-90-90 in sub-Saharan Africa-a systematic review and meta-analysis. Journal of the International AIDS Society 2020, 23(3):e25470.

12. Johnson CL, Paulose-Ram R, Ogden CL, Carroll MD, Kruszan-Moran D, Dohrmann SM, Curtin LR: National health and nutrition examination survey. Analytic guidelines, 1999-2010. 2013. 
13. Kenya Population and Housing Census. 2019, Volume I: Population by County AND Sub-County.

14. KDHS: Kenya demographic and health survey. In.: Central Bureau of Statistics, Ministry of Planning and National Development; 2003.

15. KNBS, ICF Macro: Kenya Demographic and Health Survey 2008-09. 2010. In. Calverton, Maryland: Kenya National Bureau of Statistics and ICF Macro; 2009.

16. Maina WK, Kim AA, Rutherford GW, Harper M, K'Oyugi BO, Sharif S, Kichamu G, Muraguri NM, Akhwale W, De Cock KM: Kenya AIDS Indicator Surveys 2007 and 2012: implications for public health policies for HIV prevention and treatment. Journal of acquired immune deficiency syndromes (1999) 2014, 66(Suppl 1):S130.

17. Waruiru W, Kim AA, Kimanga DO: The Kenya AIDS indicator survey 2012: rationale, methods, description of participants, and response rates. Journal of acquired immune deficiency syndromes (1999) 2014,66(Suppl 1):S3.

18. Johnson K, Way A: Risk factors for HIV infection in a national adult population: evidence from the 2003 Kenya Demographic and Health Survey. JAIDS Journal of Acquired Immune Deficiency Syndromes 2006, 42(5):627-636.

19. Gómez AM, Speizer IS, Reynolds H, Murray N, Beauvais H: Age differences at sexual debut and subsequent reproductive health: Is there a link? Reproductive health 2008, 5(1):1-8.

20. Magnusson B, Crandall A, Evans K: Early sexual debut and risky sex in young adults: The role of low self-control. BMC public health 2019, 19(1):1-8.

21. Magnusson BM, Masho SW, Lapane KL: Early age at first intercourse and subsequent gaps in contraceptive use. Journal of Women's Health 2012, 21(1):73-79.

22. O'Donnell L, O'Donnell CR, Stueve A: Early sexual initiation and subsequent sex-related risks among urban minority youth: the reach for health study. Family planning perspectives 2001:268-275.

23. Ante-Testard PA, Benmarhnia T, Bekelynck A, Baggaley R, Ouattara E, Temime L, Jean K: Temporal trends in socioeconomic inequalities in HIV testing: an analysis of cross-sectional surveys from 16 sub-Saharan African countries. The Lancet Global Health 2020, 8(6):e808-e818.

24. Okeafor CU, Okeafor IN: Trends in sexual risk behavior, HIV knowledge and testing among reproductive-aged women in Nigeria: DHS 2003-2013. HIV/AIDS Review International Journal of HIV-Related Problems 2017, 16(2):107-111.

25. Achia TN, Obayo E: Trends and correlates of HIV testing amongst women: lessons learnt from Kenya. African Journal of Primary Health Care Family Medicine 2013, 5(1).

26. Davis WW: Examining trends and averages using combined cross-sectional survey data from multiple years. J Los Angeles, California: UCLA Center for Health Policy Research 2007.

27. Lee S, Davis W, Nguyen H, McNeel T, Brick J, Flores-Cervantes I: Examining trends and averages using combined cross-sectional survey data from multiple years. CHIS Methodology Paper 2007:1-24.

28. Eaton JW, Rehle TM, Jooste S, Nkambule R, Kim AA, Mahy M, Hallett TB: Recent HIV prevalence trends among pregnant women and all women in sub-Saharan Africa: implications for HIV estimates. JAIDS 2014, 28(4):S507.

29. Kimanga DO, Ogola S, Umuro M: Prevalence and incidence of HIV infection, trends, and risk factors among persons aged 15-64 years in Kenya: results from a nationally representative study. Journal of acquired immune deficiency syndromes 2014, 66(Suppl 1):S13.

30. Yuen CM, Weyenga HO, Kim AA, Malika T, Muttai H, Katana A, Nganga L, Cain KP, De Cock KM: Comparison of trends in tuberculosis incidence among adults living with HIV and adults without HIV-Kenya, 1998-2012. PloS one 2014, 9(6):e99880.

31. Macro IJN, Kenya. https://dhsprogram. com/pubs/pdf/fr308/fr308. pdf: Kenya demographic and health survey 2014.2014.

32. Marston M, Slaymaker E, Cremin I, Floyd S, McGrath N, Kasamba I, Lutalo T, Nyirenda M, Ndyanabo A, Mupambireyi Z: Trends in marriage and time spent single in sub-Saharan Africa: a comparative analysis of six population-based cohort studies and nine Demographic and Health Surveys. Sexually transmitted infections 2009, 85(Suppl 1):i64-i71.

33. Slaymaker E, Bwanika JB, Kasamba I, Lutalo T, Maher D, Todd J: Trends in age at first sex in Uganda: evidence from Demographic and Health Survey data and longitudinal cohorts in Masaka and Rakai. Sexually transmitted infections 2009, 85(Suppl 1):i12-i19.

34. Zaba B, Boerma T, Pisani E, Baptiste N: Estimation of levels and trends in age at first sex from surveys using survival analysis. MEASURE Evaluation Project, Carolina Population Center Working Paper 2002(0251).

35. Kharsany AB, Frohlich JA, Yende-Zuma N, Mahlase G, Samsunder N, Dellar RC, Zuma-Mkhonza M, Karim SSA, Karim QA: Trends in HIV prevalence in pregnant women in rural South Africa. Journal of acquired immune deficiency syndromes (1999) 2015, $70(3): 289$.

36. Asamoah-Odei E, Calleja JMG, Boerma JT: HIV prevalence and trends in sub-Saharan Africa: no decline and large subregional differences. The Lancet 2004, 364(9428):35-40.

37. Hessol NA, Eng M, Vu A, Pipkin S, Hsu LC, Scheer S: A longitudinal study assessing differences in causes of death among housed and homeless people diagnosed with HIV in San Francisco. BMC public health 2019, 19(1):1-12.

38. Torres TS, Cardoso SW, Velasque LdS, Marins LMS, Oliveira MSd, Veloso VG, Grinsztejn B: Aging with HIV: an overview of an urban cohort in Rio de Janeiro (Brazil) across decades of life. Brazilian Journal of Infectious Diseases 2013, 17(3):324-331. 


\section{Tables}

Table 1 Summary of survey designs and HIV testing for KAIS 2007, KAIS 2012 and KENPHIA 2018

\begin{tabular}{|c|c|c|c|c|c|c|}
\hline Survey & $\begin{array}{l}\text { Survey } \\
\text { dates }\end{array}$ & Design & Interviews & $\begin{array}{l}\text { Sample for HIV } \\
\text { module }\end{array}$ & $\begin{array}{l}\text { Target } \\
\text { population }\end{array}$ & Sampling frame \\
\hline $\begin{array}{l}\text { KAIS } \\
2007\end{array}$ & $\begin{array}{l}\text { August- } \\
\text { December, } \\
2007\end{array}$ & $\begin{array}{l}\text { Two-stage stratified cluster sample, where } \\
\text { the first stage included selection of } 415 \\
\text { clusters from the NASSEP IV, stratified by } \\
\text { district and residency, and for urban areas, } \\
\text { by socio-economic status, and the second } \\
\text { stage included selection of } 25 \text { households } \\
\text { within each selected cluster. }\end{array}$ & $\begin{array}{l}9,691 \\
\text { households, } \\
17,940 \\
\text { adults and } \\
\text { adolescents } \\
\text { aged 15-64 } \\
\text { years. }\end{array}$ & $\begin{array}{l}\text { Collected } 15,853 \\
\text { blood specimens } \\
\text { from } 9,049 \\
\text { women and } \\
6,804 \text { men. }\end{array}$ & $\begin{array}{l}\text { De facto } \\
\text { household } \\
\text { resident } \\
\text { adults and } \\
\text { adolescents } \\
\text { aged } 15-64 \\
\text { years }\end{array}$ & $\begin{array}{l}\text { National Sample } \\
\text { Survey and } \\
\text { Evaluation } \\
\text { Programme } \\
\text { (NASSEP) IV } \\
\text { developed from } \\
1999 \text { census; } \\
\text { comprised of } \\
\text { 1,800 clusters. }\end{array}$ \\
\hline $\begin{array}{l}\text { KAIS } \\
2012\end{array}$ & $\begin{array}{l}\text { October } \\
29,2012 \\
\text { to } \\
\text { February } \\
3,2013\end{array}$ & $\begin{array}{l}\text { Two-stage stratified cluster sample, where } \\
\text { the first stage included selection of } 372 \\
\text { clusters from NASSEP V, stratified by } \\
\text { county and residency, and the second } \\
\text { stage included selection of } 25 \text { households } \\
\text { within each selected cluster. For the child } \\
\text { sample, every other household was } \\
\text { selected. }\end{array}$ & $\begin{array}{l}8,035 \\
\text { households, } \\
13,720 \\
\text { adults and } \\
\text { adolescents } \\
\text { aged } 15-64 \\
\text { years and } \\
1,661 \\
\text { children } \\
\text { aged } 10-14 .\end{array}$ & $\begin{array}{l}\text { Collected } 15,966 \\
\text { blood specimens } \\
\text { from } 4,832 \\
\text { women and } \\
6,785 \text { men; } 2,131 \\
\text { girls and } 2208 \\
\text { boys aged } 18 \\
\text { months to } 14 \\
\text { years. }\end{array}$ & $\begin{array}{l}\text { De facto } \\
\text { household } \\
\text { resident } \\
\text { children aged } \\
18 \text { months to } \\
14 \text { years; } \\
\text { adults and } \\
\text { adolescents } \\
\text { aged } 15 \text { to } 64 \\
\text { years }\end{array}$ & $\begin{array}{l}\text { NASSEP V } \\
\text { developed from } \\
2009 \text { census; } \\
\text { comprised of } \\
5,360 \text { clusters. }\end{array}$ \\
\hline $\begin{array}{l}\text { KENPHIA } \\
2018\end{array}$ & $\begin{array}{l}\text { June } \\
2018 \text { to } \\
\text { February } \\
2019\end{array}$ & $\begin{array}{l}\text { Two-stage, stratified cluster sample design } \\
\text { where the first stage included selection of } \\
800 \text { clusters from NASSEP V and the } \\
\text { second stage included selection of } 25 \\
\text { households within each selected cluster. } \\
\text { For child sample, every third household } \\
\text { was selected. }\end{array}$ & $\begin{array}{l}16,918 \\
\text { households, } \\
30,384 \\
\text { adults and } \\
\text { adolescents } \\
\text { aged 15-64 } \\
\text { years and } \\
2,687 \\
\text { children } \\
\text { aged 10-14. }\end{array}$ & $\begin{array}{l}\text { Collected } 35,610 \\
\text { blood specimens } \\
\text { from } 11,726 \\
\text { men and } 16,019 \\
\text { women; } 4090 \\
\text { boys and } 3775 \\
\text { girls. }\end{array}$ & $\begin{array}{l}\text { De facto } \\
\text { household } \\
\text { resident } \\
\text { children aged } \\
0-14 \text { years; } \\
\text { Adults and } \\
\text { adolescents } \\
\text { aged } 15 \text { to } 64 \\
\text { years }\end{array}$ & NASSEP V \\
\hline
\end{tabular}

Abbreviations: NASSEP-National Sample Survey and Evaluation Programme; KAIS- Kenya AIDS Indicator survey; KENPHIA- Kenya Population-based HIV Impact Assessment.

Table 2 Variables included in the combined dataset for KAIS 2007, KAIS 2012 and KENPHIA 2018 


\begin{tabular}{|c|c|c|c|c|c|}
\hline Variable & Label & 2007 & 2012 & 2018 & Combined dataset \\
\hline testedpastyear & & $\begin{array}{l}\text { Created by using the } \\
\text { variables } q 612 \text { and } \\
q 612\end{array}$ & $\begin{array}{l}\text { Created by recoding } \\
\text { the variable } \\
\text { hivtest_year }\end{array}$ & testedreceived 12 months & \\
\hline age & $\begin{array}{l}\text { Age of } \\
\text { respondent } \\
\text { (5-year age } \\
\text { ands) }\end{array}$ & $\begin{array}{l}\text { Recoded the numeric } \\
\text { variable } Q 103\end{array}$ & $\begin{array}{l}\text { Used the } 10 \text { category } \\
\text { agecat5 }\end{array}$ & $\begin{array}{l}\text { Recoded the categorical } \\
\text { variable agegroup }\end{array}$ & $\begin{array}{l}0=\text { "0-14"; } 1=\text { "15-19"; } 2=\text { "20- } \\
24 " ; 3=\text { "25-29"; } 4=\text { "30-34"; } 5= \\
\text { "35-39"; } 6=\text { " } 40-44 " ; 7=\text { " } 45-49 " ; \\
8=\text { "50-54"; = "55-59"; } 10= \\
\text { "60-64"; } 11=\text { "65+"; }\end{array}$ \\
\hline sex & $\begin{array}{l}\text { Sex of the } \\
\text { respondent }\end{array}$ & $\begin{array}{l}\text { Used the variable } \\
\text { sex as provide in the } \\
\text { dataset }\end{array}$ & $\begin{array}{l}\text { Used the variable } \\
\text { sex as provide in the } \\
\text { dataset }\end{array}$ & $\begin{array}{l}\text { Used the variable Sex as } \\
\text { provide in the dataset }\end{array}$ & 1 = "Male"; 2 = "Female" \\
\hline residence & $\begin{array}{l}\text { Place of } \\
\text { residence }\end{array}$ & $\begin{array}{l}\text { Recoded the } \\
\text { categorical variable } \\
\text { QRESID }\end{array}$ & $\begin{array}{l}\text { Recoded the } \\
\text { categorical variable } \\
\text { qresid }\end{array}$ & $\begin{array}{l}\text { Renamed the variable } \\
\text { urban }\end{array}$ & 1 = "Urban"; 2 = "Rural" \\
\hline educ3 & $\begin{array}{l}\text { Level of } \\
\text { education }\end{array}$ & $\begin{array}{l}\text { Create from } q 104 \\
\text { and } q 105\end{array}$ & $\begin{array}{l}\text { Create from } q 103 \\
\text { and } q 104\end{array}$ & Used the variable SCHLAT & $\begin{array}{l}1=\text { "No education"; } 2 \text { = } \\
\text { "Primary"; } 3 \text { = "Secondary+" }\end{array}$ \\
\hline mstatus & $\begin{array}{l}\text { Marital } \\
\text { status }\end{array}$ & $\begin{array}{l}\text { Recoded the } \\
\text { categorical variable } \\
\text { MARITAL } 1\end{array}$ & $\begin{array}{l}\text { Recoded the } \\
\text { categorical variable } \\
\text { marital3 }\end{array}$ & $\begin{array}{l}\text { Used the variables } \\
\text { evermar and curmar } \\
\text { create the marital status } \\
\text { variable }\end{array}$ & $\begin{array}{l}1=\text { "Never married"; } 2= \\
\text { "Separated/Divorced/Widowed" } \\
3=\text { "Married/Living together" }\end{array}$ \\
\hline wealthind & $\begin{array}{l}\text { Wealth } \\
\text { index }\end{array}$ & $\begin{array}{l}\text { Used the variable } \\
\text { WLTHIND5 }\end{array}$ & $\begin{array}{l}\text { Used the variable } \\
\text { windex } 5\end{array}$ & $\begin{array}{l}\text { Used the variable } \\
\text { wealthquintile }\end{array}$ & $\begin{array}{l}1 \text { = "Poorest"; } 2 \text { = "Poorer"; } 3 \text { = } \\
\text { "Middle"; } 4 \text { = "Richer"; } 5 \text { = } \\
\text { "Richest" }\end{array}$ \\
\hline year & $\begin{array}{l}\text { Year of } \\
\text { survey }\end{array}$ & $\begin{array}{l}\text { Created the variable, } \\
\text { setting survey year to } \\
\text { all respondents }\end{array}$ & $\begin{array}{l}\text { Created the variable, } \\
\text { setting survey year } \\
\text { to all respondents }\end{array}$ & $\begin{array}{l}\text { Created the variable, } \\
\text { setting survey year to all } \\
\text { respondents }\end{array}$ & $\begin{array}{l}1=\text { ="2007"; } 2 \text { = "2012"; } 3 \text { = } \\
\text { "2018” }\end{array}$ \\
\hline agefirstsex & $\begin{array}{l}\text { Age at first } \\
\text { sex (in } \\
\text { years) }\end{array}$ & $\begin{array}{l}\text { Used the variable } \\
\text { eversex and } \\
\text { agefirstsex to create } \\
\text { the age at first sex } \\
\text { variable. The age at } \\
\text { first sex for } \\
\text { individuals who had } \\
\text { not had sex by the } \\
\text { date of the survey } \\
\text { were rights censored } \\
\text { and were treated as } \\
\text { their age at that time }\end{array}$ & $\begin{array}{l}\text { Used the variable } \\
\text { eversex and } \\
\text { agefirstsex to create } \\
\text { the age at first sex } \\
\text { variable. The age at } \\
\text { first sex for } \\
\text { individuals who had } \\
\text { not had sex by the } \\
\text { date of the survey } \\
\text { were rights censored } \\
\text { and were treated as } \\
\text { their age at that } \\
\text { time }\end{array}$ & $\begin{array}{l}\text { Used the variable sexever } \\
\text { and firstsxage to create } \\
\text { the age at first sex } \\
\text { variable. The age at first } \\
\text { sex for individuals who } \\
\text { had not had sex by the } \\
\text { date of the survey were } \\
\text { rights censored and were } \\
\text { treated as their age at that } \\
\text { time }\end{array}$ & Continuous variable \\
\hline age1sex & $\begin{array}{l}\text { Age at } \\
\text { sexual } \\
\text { debut }\end{array}$ & $\begin{array}{l}\text { Similar to agefirstsex } \\
\text { but used in the } \\
\text { assessment of early } \\
\text { sexual debut }\end{array}$ & $\begin{array}{l}\text { Created in the same } \\
\text { way as in the case of } \\
\text { the } 2007 \text { survey }\end{array}$ & $\begin{array}{l}\text { Created in the same way } \\
\text { as in the case of the } 2007 \\
\text { survey }\end{array}$ & Continuous variable \\
\hline Cstatus & $\begin{array}{l}\text { Censor } \\
\text { status }\end{array}$ & $\begin{array}{l}\text { A variable used in the } \\
\text { time to event } \\
\text { analysis which takes } \\
\text { a value if the } \\
\text { age1sex is less that } \\
15 \text { years and } 0 \\
\text { otherwise. }\end{array}$ & $\begin{array}{l}\text { Created in the same } \\
\text { way as in the case of } \\
\text { the } 2007 \text { survey }\end{array}$ & $\begin{array}{l}\text { Created in the same way } \\
\text { as in the case of the } 2007 \\
\text { survey }\end{array}$ & $\begin{array}{l}1=\text { "Experienced event"; } 0= \\
\text { "Censored" }\end{array}$ \\
\hline
\end{tabular}

Abbreviations: KAIS- Kenya AIDS Indicator survey; KENPHIA- Kenya Population-based HIV Impact Assessment.

Table 3 Comparison of the distribution of participants in the 2018 survey computed using the revised and the original KENPHIA weights 
2018 with revised weights

Characteristic

Unweighted $\mathrm{n}$
2018 with KENPHIA original weights

Weighted \% (95\% Cl)

Sex

Male

12374

$49.3(48.6-50.0)$

$49.5(48.7-50.2)$

Female

16574

$50.7(50.0$ - 51.4)

50.5 (49.8 - 51.3)

Total

28948

100

100

Age

15-19

20-24

25-29

4951

$17(16.3-17.7)$

$18.9(18.2$ - 19.6)

4064

$14.6(13.8$ - 15.4)

$16.6(15.8$ - 17.4)

30-34

3841

$13.7(13.0-14.5)$

14.9 (14.2 - 15.6)

35-39

3961

14 (13.4 - 14.5)

$13.1(12.6$ - 13.6)

40-44

3006

$10.4(9.9-10.9)$

$10.6(10.1$ - 11.2)

45-49

2639

$9(8.6-9.5)$

$8.1(7.6-8.5)$

2073

6.8 (6.5 - 7.2)

$6.4(6.1-6.8)$

50-54

1730

$5.8(5.4-6.1)$

$4.9(4.6-5.1)$

55-59

1438

$4.8(4.4-5.1)$

$3.7(3.5-4)$

60-64

1245

$3.9(3.6-4.1)$

$2.8(2.6-3)$

Total

28948

100

100

Place of residence

Urban

10752

$39.3(37.2$ - 41.4$)$

$37.8(35.7$ - 40)

Rural

18196

$60.7(58.6-62.8)$

$62.2(60-64.3)$

Total

28948

100

100

Level of education

No education

2285

$6.4(5.1-7.7)$

$5.6(4.6-6.6)$

Primary

13268

47.4 (45.9 - 48.9)

42.3 (41 - 43.7)

Secondary+

13369

46.2 (44.6 - 47.9)

$52.1(50.6$ - 53.5)

Total

28922

100

100

Marital status

Never married

8976

34.7 (33.7 - 35.6)

37.8 (36.8 - 38.8)

Separated/Divorced/Widowed

1888

$6(5.6-6.4)$

$5.2(4.9-5.6)$

Married/Living together

16473

$59.4(58.3-60.4)$

57 (55.9 - 58.1)

Total

27337

100

100

Wealth index

\begin{tabular}{llll} 
Poorest & 7058 & $19.3(17.5-21.1)$ & $19.5(17.9-21.1)$ \\
\hline Poorer & 6574 & $21(19.7-22.3)$ & $21.8(20.5-23)$ \\
\hline Middle & 6209 & $20.3(19.1-21.5)$ & $21(19.7-22.2)$ \\
\hline Richer & 5370 & $19.7(18.0-21.3)$ & $19.5(18-21)$ \\
\hline Richest & 3732 & $19.7(17.5-22.0)$ & $18.3(16.2-20.4)$ \\
\hline Total & 28943 & 100 & 100
\end{tabular}

Abbreviations: Cl- Confidence Interval; KENPHIA- Kenya Population-based HIV Impact Assessment

Page 12/22 
Table 4 Demographic characteristics of interviewed study participants age 15-64 years in KAIS 2007, KAIS 2012 and KENPHIA 2018

Page $13 / 22$ 


\begin{tabular}{|c|c|c|c|c|c|}
\hline & 2007 & 2012 & 2018 & Total & P-Value \\
\hline Characteristic & Weighted \% (95\% Cl) & Weighted \% (95\% Cl) & Weighted \% $(95 \% \mathrm{Cl})$ & Weighted \% (95\% Cl) & \\
\hline Sex & & & & & $<.001$ \\
\hline Male & $42.9(42.0-43.8)$ & $49(48.0-50.0)$ & $49.3(48.6-50.0)$ & $46.8(46.1-47.6)$ & \\
\hline Female & $57.1(56.2-58.0)$ & $51(50.0-52.0)$ & $50.7(50.0-51.4)$ & $53.2(52.4-53.9)$ & \\
\hline Total & 100 & 100 & 100 & 100 & \\
\hline Age of the respondent & & & & & $<.001$ \\
\hline $15-19$ & 16.8(16.0 - 17.5) & $16.8(15.8-17.7)$ & $17(16.3-17.7)$ & $16.8(16.1-17.4)$ & \\
\hline $20-24$ & $16.9(16.1-17.7)$ & 16.3(15.4 - 17.1) & $14.6(13.8-15.4)$ & $16.5(15.9-17.1)$ & \\
\hline $25-29$ & 13.9(13.3 - 14.6) & $15.6(14.8-16.4)$ & $13.7(13.0-14.5)$ & $15(14.4-15.6)$ & \\
\hline $30-34$ & $11.8(11.2-12.5)$ & $12.3(11.7-13.0)$ & $14(13.4-14.5)$ & $12.2(11.7-12.6)$ & \\
\hline $35-39$ & $10.5(9.9-11.0)$ & $10.4(9.8-11.0)$ & $10.4(9.9-10.9)$ & $10.4(10.0-10.9)$ & \\
\hline $40-44$ & $8.1(7.6-8.6)$ & $8.5(8.0-9.0)$ & $9(8.6-9.5)$ & $8.4(8.0-8.8)$ & \\
\hline $45-49$ & $7.9(7.4-8.4)$ & $6.2(5.8-6.7)$ & $6.8(6.5-7.2)$ & $6.8(6.5-7.2)$ & \\
\hline $50-54$ & $5.4(5.0-5.8)$ & $6.1(5.7-6.6)$ & $5.8(5.4-6.1)$ & $5.9(5.5-6.2)$ & \\
\hline $55-59$ & $5.2(4.8-5.6)$ & $4.3(3.9-4.8)$ & $4.8(4.4-5.1)$ & $4.6(4.3-4.9)$ & \\
\hline $60-64$ & $3.5(3.2-3.9)$ & $3.4(3.0-3.8)$ & $3.9(3.6-4.1)$ & $3.5(3.2-3.7)$ & \\
\hline Total & 100 & 100 & 100 & 100 & \\
\hline Place of residence & & & & & $<.001$ \\
\hline Urban & 22.3(19.7 - 24.9) & $37.1(34.7-39.5)$ & $39.3(37.2-41.4)$ & $31.8(30.1$ - 33.6) & \\
\hline Rural & $77.7(75.1$ - 80.3) & $62.9(60.5-65.3)$ & $60.7(58.6-62.8)$ & $68.2(66.4-69.9)$ & \\
\hline Total & 100 & 100 & 100 & 100 & \\
\hline Level of education & & & & & $<.001$ \\
\hline No education & $10.6(9.5-11.7)$ & $7.3(6.0-8.6)$ & $6.4(5.1-7.7)$ & $8.5(7.5-9.4)$ & \\
\hline Primary & $55.7(54.0-57.5)$ & $59.4(57.3-61.5)$ & $47.4(45.9-48.9)$ & $58.1(56.6-59.6)$ & \\
\hline Secondary+ & $33.7(31.8-35.5)$ & $33.3(31.2$ - 35.4) & $46.2(44.6-47.9)$ & $33.4(32.0-34.9)$ & \\
\hline Total & 100 & 100 & 100 & 100 & \\
\hline Marital status & & & & & $<.001$ \\
\hline Never married & $29.2(28.1-30.3)$ & $33.6(32.2-34.9)$ & $34.7(33.7-35.6)$ & $32(31.0-32.9)$ & \\
\hline Separated/Divorced/Widowed & 10.6(10.0 - 11.2) & $4.2(3.8-4.6)$ & $6(5.6-6.4)$ & $6.5(6.1-6.9)$ & \\
\hline Married/Living together & $60.3(59.0-61.5)$ & $62.3(60.9-63.7)$ & $59.4(58.3-60.4)$ & $61.5(60.6-62.5)$ & \\
\hline Total & 100 & 100 & 100 & 100 & \\
\hline Wealth index & & & & & $<.001$ \\
\hline Poorest & $14.7(13.0-16.5)$ & $19.2(16.6-21.8)$ & $19.3(17.5-21.1)$ & $17.6(15.8-19.4)$ & \\
\hline Poorer & $18.2(16.6-19.8)$ & $20.8(18.9-22.7)$ & $21(19.7-22.3)$ & $19.9(18.5-21.2)$ & \\
\hline Middle & $20.3(18.8-21.8)$ & $19.8(17.9-21.7)$ & $20.3(19.1-21.5)$ & $20(18.7-21.3)$ & \\
\hline Richer & $21.7(19.9-23.4)$ & $19.3(17.2-21.4)$ & $19.7(18.0-21.3)$ & $20.1(18.6-21.6)$ & \\
\hline Richest & $25.1(22.4-27.8)$ & $20.8(18.1-23.6)$ & $19.7(17.5-22.0)$ & $22.3(20.4-24.3)$ & \\
\hline Total & 100 & 100 & 100 & 100 & \\
\hline
\end{tabular}

Abbreviations: Cl- Confidence Interval; KAIS- Kenya AIDS Indicator survey; KENPHIA- Kenya Population-based HIV Impact Assessment. 
Table 5 Trends and regression results for age at first sex by selected covariates in KAIS 2007, KAIS 2012 and KENPHIA 2018

Page 15/22 


\begin{tabular}{|c|c|c|c|c|c|c|c|}
\hline Variable & $\mathbf{N}$ & Mean $(95 \% \mathrm{Cl})$ & $\begin{array}{l}\text { Median } \\
\text { (Range) }\end{array}$ & $\begin{array}{l}\text { Unadjusted b (95\% } \\
\text { Cl) }\end{array}$ & $\begin{array}{l}p- \\
\text { value }\end{array}$ & $\begin{array}{l}\text { Adjusted b (95\% } \\
\text { CI) }\end{array}$ & $\begin{array}{l}p- \\
\text { value }\end{array}$ \\
\hline \multicolumn{8}{|l|}{ Year of survey } \\
\hline 2007 & 16,285 & $\begin{array}{l}17.2(17.1- \\
17.3)\end{array}$ & $16.4(47)$ & Reference & & Reference & \\
\hline 2012 & 12,728 & $\begin{array}{l}17.7(17.6- \\
17.8)\end{array}$ & $16.8(60)$ & $0.7(0.5-0.9)$ & $<0.001$ & $0.7(0.5-0.9)$ & $<0.001$ \\
\hline 2018 & 29,250 & $\begin{array}{l}17.7(17.6- \\
17.8)\end{array}$ & $17(63)$ & $0.6(0.5-0.8)$ & $<0.001$ & $0.6(0.5-0.8)$ & $<0.001$ \\
\hline \multicolumn{8}{|l|}{ Sex } \\
\hline Female & 33,030 & $\begin{array}{l}17.5(17.3- \\
17.6)\end{array}$ & $16.6(60)$ & Reference & & Reference & \\
\hline Male & 25,233 & $\begin{array}{l}17.6(17.5- \\
17.7)\end{array}$ & 16.7(63) & $-0.2(-0.4-0)$ & 0.0237 & $0.1(-0.1-0.2)$ & 0.4606 \\
\hline \multicolumn{8}{|l|}{ Age of the respondent } \\
\hline $25-29$ & 8,203 & $17.9(17.7-18)$ & 17.1(45) & Reference & & Reference & \\
\hline $30-34$ & 7,468 & $18.2(18-18.4)$ & 17.2(33) & $0.7(0.4-0.9)$ & $<0.001$ & $0.4(0.1-0.6)$ & 0.0025 \\
\hline $35-39$ & 5,948 & 18(17.8-18.1) & $17(44)$ & $0.6(0.4-0.9)$ & $<0.001$ & $0.1(-0.1-0.4)$ & 0.3097 \\
\hline $40-44$ & 5,004 & $\begin{array}{l}18.1(17.8- \\
18.3)\end{array}$ & $17(49)$ & $0.7(0.4-1)$ & $<0.001$ & $0.2(-0.1-0.5)$ & 0.1792 \\
\hline $45-49$ & 4,024 & $\begin{array}{l}17.9(17.7- \\
18.2)\end{array}$ & $17(60)$ & $0.7(0.4-1)$ & $<0.001$ & $0(-0.3-0.3)$ & 0.7978 \\
\hline $50-54$ & 3,334 & 18(17.7-18.3) & 17.1(53) & $0.8(0.5-1.2)$ & $<0.001$ & $0.1(-0.2-0.5)$ & 0.392 \\
\hline $55-59$ & 2,716 & $\begin{array}{l}17.9(17.5- \\
18.2)\end{array}$ & $17(57)$ & $0.9(0.5-1.3)$ & $<0.001$ & $0(-0.3-0.4)$ & 0.9024 \\
\hline $60-64$ & 2,139 & 18.4(18-18.8) & $17.4(63)$ & $1.4(1-1.9)$ & $<0.001$ & $0.5(0.1-1)$ & 0.0206 \\
\hline \multicolumn{8}{|l|}{ Place of residence } \\
\hline Urban & 19,922 & 18(17.8-18.2) & 17.1(63) & Reference & & Reference & \\
\hline Rural & 38,341 & $\begin{array}{l}17.3(17.2- \\
17.4)\end{array}$ & $16.4(60)$ & $0.1(-0.2-0.4)$ & 0.4359 & $-0.8(-1-0.5)$ & $<0.001$ \\
\hline \multicolumn{8}{|l|}{ Level of education } \\
\hline No education & 7,510 & $\begin{array}{l}16.6(16.4- \\
16.8)\end{array}$ & $15.5(63)$ & Reference & & Reference & \\
\hline Primary & 28,816 & $\begin{array}{l}17.5(17.4- \\
17.6)\end{array}$ & $16.7(60)$ & $0.7(0.4-1)$ & $<0.001$ & $0.9(0.6-1.1)$ & $<0.001$ \\
\hline Secondary+ & 21,907 & 18.2(18-18.3) & $17.3(57)$ & $0.9(0.6-1.2)$ & $<0.001$ & $1.3(1-1.6)$ & $<0.001$ \\
\hline \multicolumn{8}{|l|}{ Marital status } \\
\hline Never married & 18,491 & $\begin{array}{l}17.3(17.2- \\
17.4)\end{array}$ & $16.3(63)$ & Reference & & Reference & \\
\hline Married/Living together & 3,992 & $17.2(17-17.4)$ & $16.3(60)$ & $-1.7(-2-1.3)$ & $<0.001$ & $-1.7(-2.1-1.4)$ & $<0.001$ \\
\hline Separated/Divorced/Widowed & 33,603 & $\begin{array}{l}17.7(17.6- \\
17.8)\end{array}$ & $16.9(59)$ & $-2.2(-2.6-1.8)$ & $<0.001$ & $-2.3(-2.7-1.9)$ & $<0.001$ \\
\hline \multicolumn{8}{|l|}{ Wealth index } \\
\hline Poorest & 12,631 & $\begin{array}{l}16.9(16.7- \\
17.1)\end{array}$ & 16(59) & Reference & & Reference & \\
\hline Middle & 12,004 & $\begin{array}{l}17.1(16.9- \\
17.2)\end{array}$ & $16.2(57)$ & $0.5(0.3-0.8)$ & $<0.001$ & $0.7(0.4-1)$ & $<0.001$ \\
\hline Poorer & 11,760 & $\begin{array}{l}17.4(17.3- \\
17.5)\end{array}$ & $16.6(63)$ & $0.3(0-0.5)$ & 0.0408 & $0.4(0.1-0.7)$ & 0.0073 \\
\hline
\end{tabular}




\begin{tabular}{|c|c|c|c|c|c|c|c|}
\hline Richer & 11,143 & $\begin{array}{l}17.7(17.6- \\
17.8)\end{array}$ & $16.9(51)$ & $0.8(0.5-1.1)$ & $<0.001$ & $0.9(0.6-1.2)$ & $<0.001$ \\
\hline Richest & 10,720 & $\begin{array}{l}18.4(18.2- \\
18.6)\end{array}$ & $17.4(57)$ & $1.6(1.2-1.9)$ & $<0.001$ & $1.7(1.3-2.1)$ & $<0.001$ \\
\hline
\end{tabular}

Abbreviations: Cl- Confidence Interval; KAIS- Kenya AIDS Indicator survey; KENPHIA- Kenya Population-based HIV Impact Assessment.

Table 6 Person-time analysis and survey-weighted Cox-regression of age at sexual debut by selected covariates in KAIS 2007 , KAIS 2012 and KENPHIA 2018 


\begin{tabular}{|c|c|c|c|c|c|c|c|}
\hline \multirow[t]{2}{*}{ Variable } & \multicolumn{3}{|c|}{ Person-time analysis } & \multicolumn{4}{|c|}{ Survey-weighted Cox-regression } \\
\hline & Event & Person-time & Rate $(95 \% \mathrm{Cl})$ & $\mathrm{HR}(95 \% \mathrm{Cl})$ & p-value & $\operatorname{AHR}(95 \% \mathrm{Cl})$ & p-value \\
\hline \multicolumn{8}{|l|}{ Year } \\
\hline 2007 & 2,260 & 282,820 & 7.99(7.67-8.33) & 1.00 (Reference) & & 1.00 (Reference) & \\
\hline 2012 & 1,509 & 225,945 & $6.68(6.35-7.02)$ & $0.91(0.83-0.99)$ & 0.0263 & $0.93(0.85-1.02)$ & 0.1047 \\
\hline 2018 & 3,416 & 515,749 & $6.62(6.4-6.85)$ & $0.78(0.73-0.84)$ & $<0.001$ & $0.76(0.71-0.82)$ & $<0.001$ \\
\hline \multicolumn{8}{|l|}{ Sex } \\
\hline Male & 3,800 & 440,780 & 8.62(8.35-8.9) & 1.00 (Reference) & & 1.00 (Reference) & \\
\hline Female & 3,385 & 583,734 & $5.8(5.61-6)$ & $1.16(1.07-1.25)$ & $<0.001$ & $1.01(0.93-1.09)$ & 0.931 \\
\hline \multicolumn{8}{|l|}{ Age } \\
\hline 15-19 & 1,289 & 163,167 & 7.9(7.48-8.34) & 1.00 (Reference) & & 1.00 (Reference) & \\
\hline $20-24$ & 1,229 & 158,841 & $7.74(7.32-8.18)$ & $1.09(0.96-1.24)$ & 0.1683 & $1.26(1.12-1.43)$ & $<0.001$ \\
\hline $25-29$ & 1,054 & 146,573 & 7.19(6.77-7.64) & $1.17(1.02-1.35)$ & 0.0243 & $1.46(1.29-1.66)$ & $<0.001$ \\
\hline $30-34$ & 926 & 135,175 & $6.85(6.42-7.31)$ & $1.08(0.92-1.26)$ & 0.3324 & $1.45(1.26-1.67)$ & $<0.001$ \\
\hline $35-39$ & 697 & 108,151 & $6.44(5.98-6.94)$ & $1.07(0.91-1.25)$ & 0.3992 & $1.5(1.31-1.72)$ & $<0.001$ \\
\hline $40-44$ & 562 & 91,010 & $6.18(5.69-6.71)$ & $1.09(0.93-1.28)$ & 0.2736 & $1.59(1.38-1.82)$ & $<0.001$ \\
\hline $45-49$ & 449 & 72,927 & $6.16(5.61-6.75)$ & $1.14(0.97-1.34)$ & 0.1089 & $1.72(1.49-1.98)$ & $<0.001$ \\
\hline $50-54$ & 410 & 60,614 & $6.76(6.14-7.45)$ & $1.21(1.02-1.43)$ & 0.028 & $1.9(1.64-2.21)$ & $<0.001$ \\
\hline 55-59 & 322 & 48,758 & $6.6(5.92-7.37)$ & $1.14(0.94-1.37)$ & 0.1823 & $1.93(1.63-2.27)$ & $<0.001$ \\
\hline $60-64$ & 247 & 39,298 & $6.29(5.55-7.12)$ & $1.11(0.9-1.37)$ & 0.3471 & $1.89(1.54-2.31)$ & $<0.001$ \\
\hline \multicolumn{8}{|l|}{ Residence } \\
\hline Urban & 2,208 & 358,069 & $6.17(5.91-6.43)$ & 1.00 (Reference) & & 1.00 (Reference) & \\
\hline Rural & 4,977 & 666,445 & $7.47(7.26-7.68)$ & $1.13(1.02-1.26)$ & 0.0183 & $1.23(1.11-1.37)$ & $<0.001$ \\
\hline \multicolumn{8}{|l|}{ Education } \\
\hline No formal & 1,164 & 128,898 & $9.03(8.53-9.56)$ & 1.00 (Reference) & & 1.00 (Reference) & \\
\hline Primary & 3,793 & 499,413 & $7.59(7.36-7.84)$ & $0.56(0.5-0.62)$ & $<0.001$ & $0.56(0.5-0.63)$ & $<0.001$ \\
\hline Secondary+ & 2,226 & 395,692 & $5.63(5.4-5.86)$ & $0.54(0.48-0.61)$ & $<0.001$ & $0.57(0.5-0.65)$ & $<0.001$ \\
\hline \multicolumn{8}{|l|}{ Marital status } \\
\hline Never married & 2,112 & 317,944 & $6.64(6.37-6.93)$ & 1.00 (Reference) & & 1.00 (Reference) & \\
\hline Separated/Divorced/Widowed & 538 & 69,295 & 7.76(7.13-8.45) & $1.66(1.49-1.85)$ & $<0.001$ & $1.71(1.56-1.87)$ & $<0.001$ \\
\hline Married/Living together & 4,234 & 598,685 & $7.07(6.86-7.29)$ & $1.97(1.72-2.27)$ & $<0.001$ & $2.18(1.93-2.46)$ & $<0.001$ \\
\hline \multicolumn{8}{|l|}{ Wealth index } \\
\hline Poorest & 1,877 & 215,567 & $8.71(8.32-9.11)$ & 1.00 (Reference) & & 1.00 (Reference) & \\
\hline Poorer & 1,694 & 205,840 & $8.23(7.85-8.63)$ & $0.8(0.72-0.9)$ & $<0.001$ & $0.75(0.66-0.85)$ & $<0.001$ \\
\hline Middle & 1,398 & 206,487 & $6.77(6.42-7.13)$ & $0.87(0.78-0.96)$ & 0.0047 & $0.82(0.73-0.92)$ & $<0.001$ \\
\hline Richer & 1,249 & 198,424 & $6.29(5.96-6.65)$ & $0.7(0.62-0.8)$ & $<0.001$ & $0.65(0.57-0.75)$ & $<0.001$ \\
\hline Richest & 966 & 198,117 & $4.88(4.58-5.19)$ & $0.64(0.55-0.75)$ & $<0.001$ & $0.57(0.5-0.65)$ & $<0.001$ \\
\hline
\end{tabular}

Abbreviations: HR-Hazard rate; AHR-Adjusted Hazard rate; Cl- Confidence Interval; KAIS- Kenya AIDS Indicator survey; KENPHIA-Kenya Populationbased HIV Impact Assessment. 
Table 7 Logistic regression results for HIV in the last 12 months by selected covariates in KAIS 2007, KAIS 2012 and KENPHIA 2018

Page 19/22 


\begin{tabular}{|c|c|c|c|c|c|c|c|c|c|}
\hline Characteristic & $\begin{array}{l}\text { Unweighted } \\
\mathrm{n} / \mathrm{N}\end{array}$ & $\begin{array}{l}\text { Prevalence } \\
(95 \% \mathrm{Cl})\end{array}$ & $\begin{array}{l}\mathrm{p}- \\
\text { value }\end{array}$ & $\begin{array}{l}\mathrm{OR}(95 \% \\
\mathrm{Cl})\end{array}$ & p-value & $\begin{array}{l}\text { Global } \\
\text { p- } \\
\text { value }\end{array}$ & $\begin{array}{l}\mathrm{AOR}(95 \% \\
\mathrm{Cl})\end{array}$ & $\begin{array}{l}\mathrm{p}- \\
\text { value }\end{array}$ & $\begin{array}{l}\text { Global } \\
\text { p- } \\
\text { value }\end{array}$ \\
\hline Year of survey & & & $<.001$ & & & & & & \\
\hline 2007 & $1858 / 14392$ & $\begin{array}{l}12.6(11.6- \\
13.6)\end{array}$ & & $\begin{array}{l}1.00 \\
\text { (Reference) }\end{array}$ & & & $\begin{array}{l}1.00 \\
\text { (Reference) }\end{array}$ & & \\
\hline 2012 & $5526 / 9841$ & $\begin{array}{l}56.1(54.6- \\
57.6)\end{array}$ & & $\begin{array}{l}8.87 \text { (7.97- } \\
9.86)\end{array}$ & $<0.001$ & $<0.001$ & $\begin{array}{l}8.45(7.59- \\
9.42)\end{array}$ & $<0.001$ & $<0.001$ \\
\hline 2018 & $12764 / 22792$ & $\begin{array}{l}55.6(54.6- \\
56.6)\end{array}$ & & $\begin{array}{l}8.69(7.89- \\
9.57)\end{array}$ & $<0.001$ & & $\begin{array}{l}8.62(7.81- \\
9.51)\end{array}$ & $<0.001$ & \\
\hline Sex & & & $<.001$ & & & & & & \\
\hline Female & $12782 / 27489$ & $\begin{array}{l}40.3(39.0- \\
41.7)\end{array}$ & & $\begin{array}{l}1.00 \\
\text { (Reference) }\end{array}$ & & & $\begin{array}{l}1.00 \\
\text { (Reference) }\end{array}$ & & \\
\hline Male & $7366 / 19536$ & $\begin{array}{l}37.2(35.6- \\
38.8)\end{array}$ & & $\begin{array}{l}0.88(0.82- \\
0.94)\end{array}$ & $<0.001$ & $<0.001$ & $\begin{array}{l}0.99(0.91- \\
1.09)\end{array}$ & 0.9006 & 0.9006 \\
\hline Age of the respondent & & & $<.001$ & & & & & & \\
\hline $15-19$ & $2384 / 6205$ & $\begin{array}{l}33.2(30.8- \\
35.6)\end{array}$ & & $\begin{array}{l}1.00 \\
\text { (Reference) }\end{array}$ & & & $\begin{array}{l}1.00 \\
\text { (Reference) }\end{array}$ & & \\
\hline $20-24$ & $3858 / 7305$ & $\begin{array}{l}49.9(47.7- \\
52.0)\end{array}$ & & $\begin{array}{l}2.00(1.76- \\
2.28)\end{array}$ & $<0.001$ & $<0.001$ & $\begin{array}{l}1.4(1.21- \\
1.62)\end{array}$ & $<0.001$ & $<0.001$ \\
\hline $25-29$ & $3584 / 7044$ & $\begin{array}{l}47.3(45.0 \text { - } \\
49.6)\end{array}$ & & $\begin{array}{l}1.81(1.58- \\
2.06)\end{array}$ & $<0.001$ & & $\begin{array}{l}1.05(0.91- \\
1.22)\end{array}$ & $<0.001$ & \\
\hline $30-34$ & $3049 / 6574$ & $\begin{array}{l}41(38.7- \\
43.3)\end{array}$ & & $\begin{array}{l}1.40(1.22- \\
1.61)\end{array}$ & $<0.001$ & & $\begin{array}{l}0.85(0.7- \\
1.01)\end{array}$ & 0.3206 & \\
\hline $35-39$ & $2240 / 5278$ & $\begin{array}{l}38.2(35.8- \\
40.6)\end{array}$ & & $\begin{array}{l}1.25(1.08- \\
1.43)\end{array}$ & 0.002 & & $\begin{array}{l}0.79(0.66- \\
0.95)\end{array}$ & 0.9096 & \\
\hline $40-44$ & $1703 / 4388$ & $\begin{array}{l}34.5(31.9- \\
37.1)\end{array}$ & & $\begin{array}{l}1.06(0.91- \\
1.24)\end{array}$ & 0.458 & & $\begin{array}{l}0.7(0.57- \\
0.85)\end{array}$ & 0.0348 & \\
\hline $45-49$ & $1209 / 3574$ & $\begin{array}{l}27.1(24.4- \\
29.7)\end{array}$ & & $\begin{array}{l}0.75(0.63- \\
0.88)\end{array}$ & $<0.001$ & & $\begin{array}{l}0.6(0.48- \\
0.74)\end{array}$ & $<0.001$ & \\
\hline $50-54$ & $931 / 2818$ & $\begin{array}{l}31.1(27.9- \\
34.3)\end{array}$ & & $\begin{array}{l}0.91(0.77- \\
1.07)\end{array}$ & 0.256 & & $\begin{array}{l}0.64(0.51- \\
0.81)\end{array}$ & 0.0071 & \\
\hline $55-59$ & $677 / 2197$ & $\begin{array}{l}27(23.5- \\
30.5)\end{array}$ & & $\begin{array}{l}0.75(0.61- \\
0.91)\end{array}$ & 0.004 & & $\begin{array}{l}0.68(0.51- \\
0.9)\end{array}$ & 0.1008 & \\
\hline $60-64$ & $513 / 1642$ & $\begin{array}{l}25(20.5- \\
29.5)\end{array}$ & & $\begin{array}{l}0.67(0.52- \\
0.87)\end{array}$ & 0.002 & & $\begin{array}{l}0.59(0.43- \\
0.8)\end{array}$ & 0.0132 & \\
\hline Place of residence & & & $<.001$ & & & & & & \\
\hline Urban & $8309 / 16687$ & $\begin{array}{l}49.2(47.1 \text { - } \\
51.3)\end{array}$ & & $\begin{array}{l}1.00 \\
\text { (Reference) }\end{array}$ & & & $\begin{array}{l}1.00 \\
\text { (Reference) }\end{array}$ & & \\
\hline Rural & $11839 / 30338$ & $\begin{array}{l}33.7(32.2- \\
35.2)\end{array}$ & & $\begin{array}{l}0.53(0.47- \\
0.59)\end{array}$ & $<0.0011$ & $<0.001$ & $\begin{array}{l}0.89(0.77- \\
1.01)\end{array}$ & 0.078 & 0.078 \\
\hline Level of education & & & $<0.001$ & & & & & & \\
\hline No education & $1386 / 4096$ & $\begin{array}{l}27.4(24.0- \\
30.8)\end{array}$ & & $\begin{array}{l}1.00 \\
\text { (Reference) }\end{array}$ & & & $\begin{array}{l}1.00 \\
\text { (Reference) }\end{array}$ & & \\
\hline Primary & $9961 / 24441$ & $\begin{array}{l}38(36.6- \\
39.5)\end{array}$ & & $\begin{array}{l}1.63(1.36- \\
1.95)\end{array}$ & $<0.001$ & $<0.001$ & $\begin{array}{l}1.04(0.88- \\
1.23)\end{array}$ & 0.4343 & 0.0288 \\
\hline Secondary+ & $8801 / 18487$ & $\begin{array}{l}42.7(40.9- \\
44.5)\end{array}$ & & $\begin{array}{l}1.97(1.64- \\
2.37)\end{array}$ & $<0.001$ & & $\begin{array}{l}1.17(0.98- \\
1.4)\end{array}$ & 0.0204 & \\
\hline Marital status & & & $<.001$ & & & & & & \\
\hline Never married & $5441 / 12943$ & $\begin{array}{l}38(36.1 \text { - } \\
39.8)\end{array}$ & & $\begin{array}{l}1.00 \\
\text { (Reference) }\end{array}$ & & & $\begin{array}{l}1.00 \\
\text { (Reference) }\end{array}$ & & \\
\hline Married/Living together & $1185 / 3505$ & $\begin{array}{l}24.6(22.0 \text { - } \\
27.3)\end{array}$ & & $\begin{array}{l}1.09(1.00- \\
1.19)\end{array}$ & 0.05 & $<0.001$ & $\begin{array}{l}1.23(1.09- \\
1.39)\end{array}$ & 0.0396 & 0.005 \\
\hline
\end{tabular}

Page 20/22 


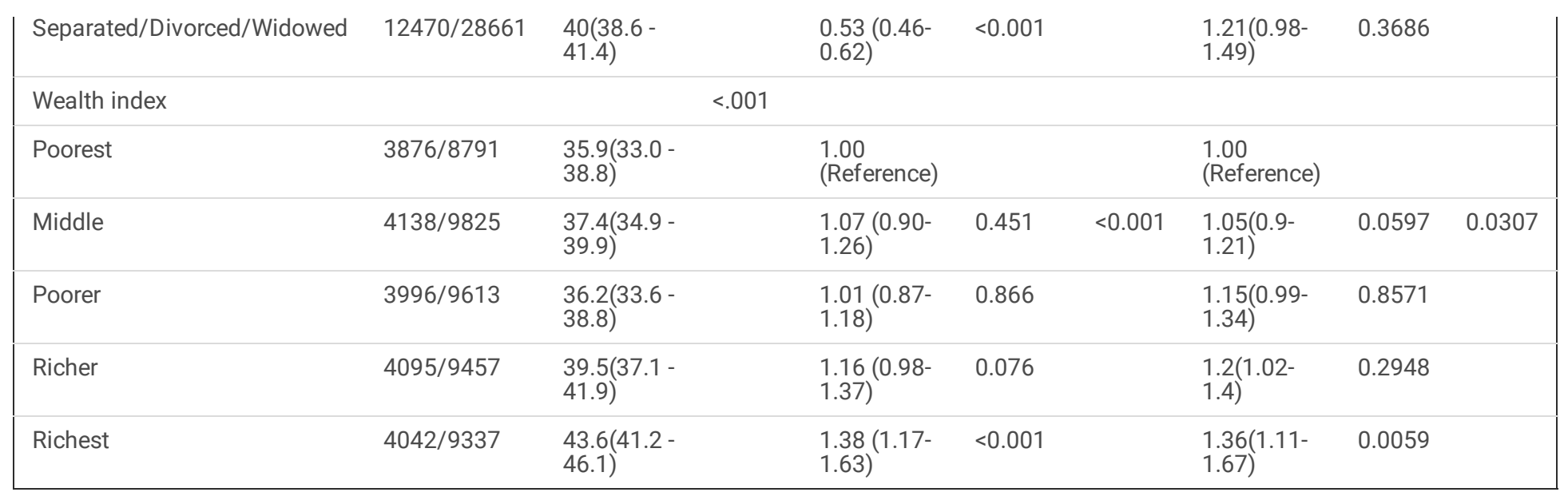

Abbreviations: OR-Odds ratio; AOR-Adjusted Odds ratio; Cl- Confidence Interval; KAIS- Kenya AIDS Indicator survey; KENPHIA- Kenya Populationbased HIV Impact Assessment.

\section{Figures}

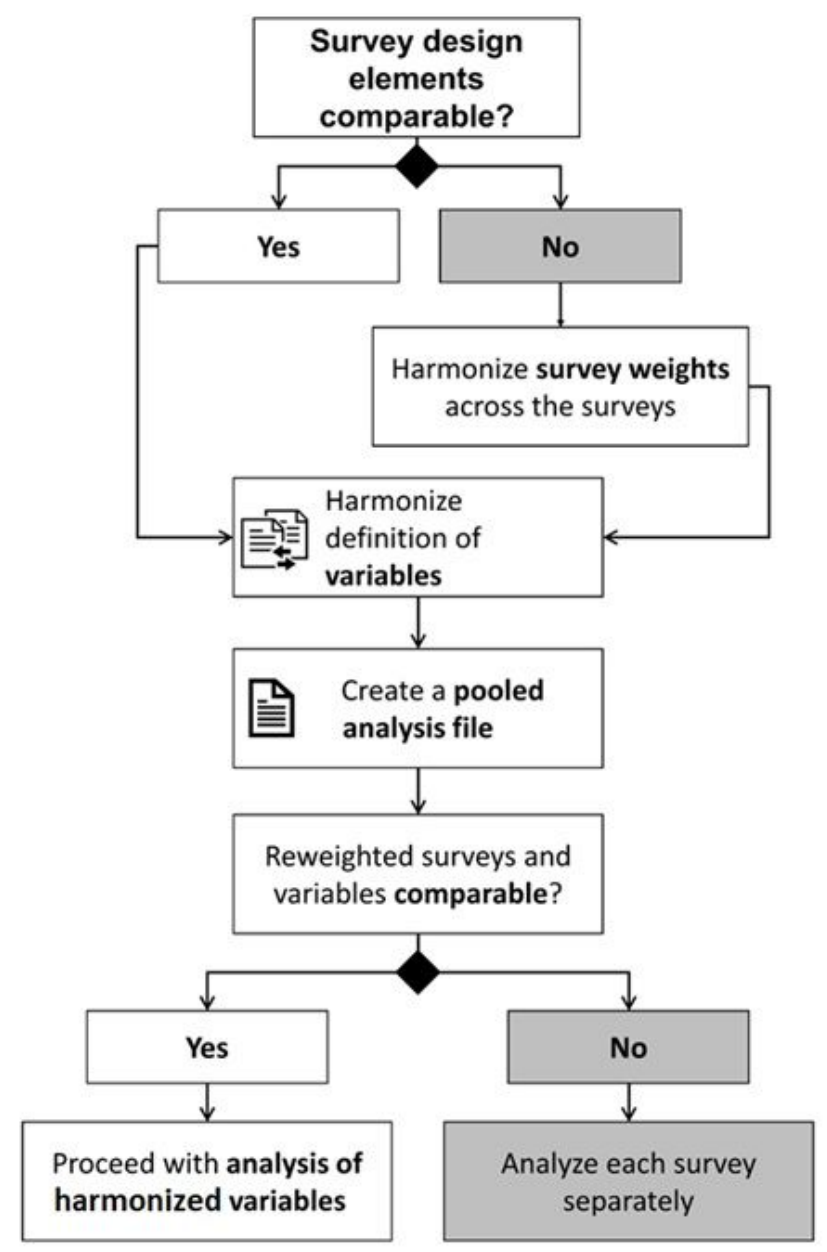

Figure 1

Preparing a trend analysis across independent surveys 


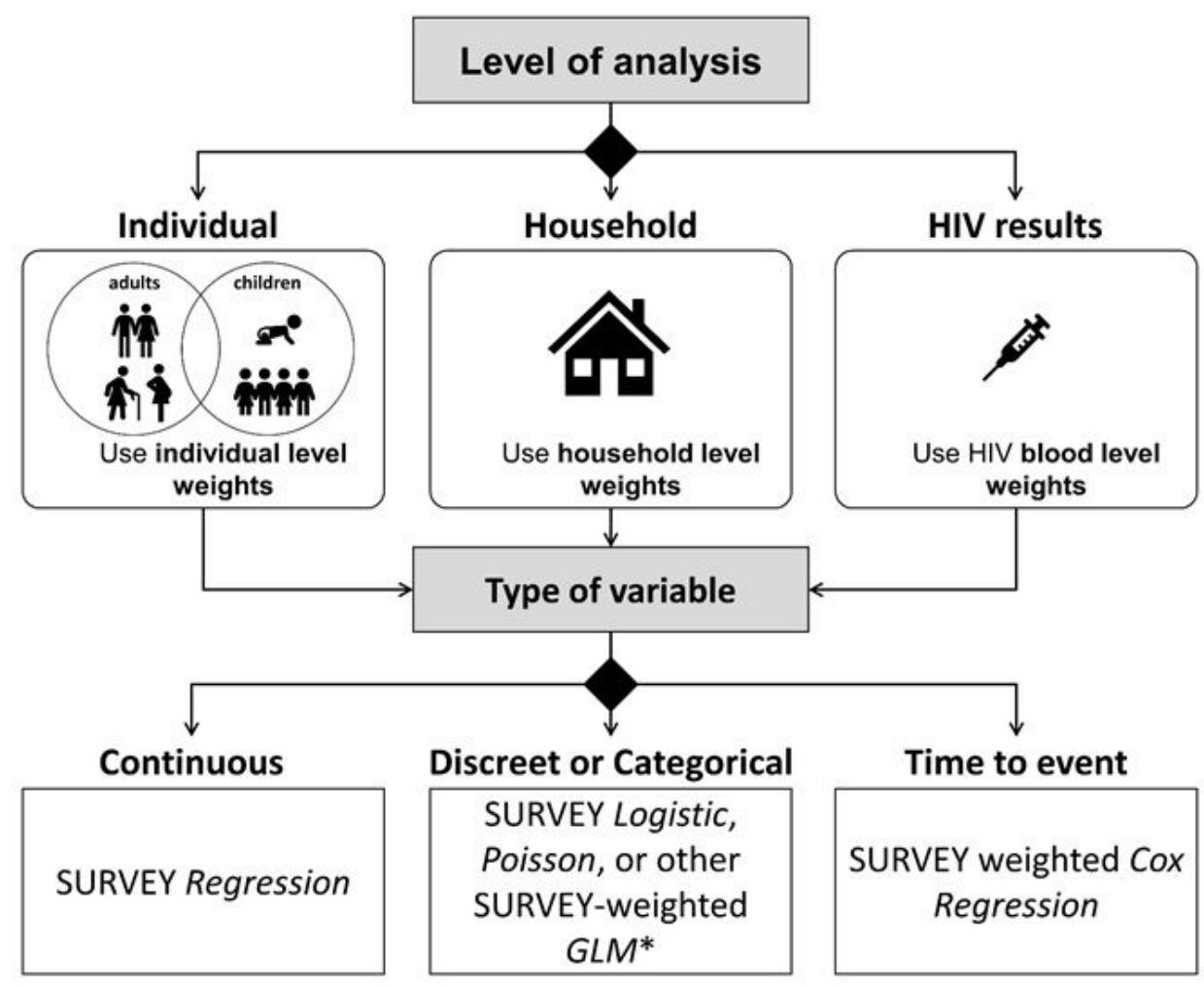

Figure 2

Choosing a statistical method based on type of variable to be analyzed in KAIS 2007, KAIS 2012 and KENPHIA 2018. Abbreviations: GLM, generalized linear model

\section{Supplementary Files}

This is a list of supplementary files associated with this preprint. Click to download.

- SupplementaryFile1.docx

- SupplementaryFile2.docx

- SupplementaryFile3.docx 